\title{
Analysis and Evaluation on Teachers' Professional Competence at Junior High School of Siau Island, Sitaro Regency
}

\author{
Julien Biringan* \\ Pancasila and Civic Education \\ Department \\ Faculty of Social Sciences, \\ Universitas Negeri Manado \\ Tondano, Indonesia \\ julienbiringan@unima.ac.id
}

\author{
Telly Delly Wua \\ Pancasila and Civic Education \\ Department \\ Faculty of Social Sciences \\ Manado Universitas Negeri Manado \\ Tondano, Indonesia \\ tellywua@unima.ac.id
}

\author{
Maxi Keintjem \\ Pancasila and Civic Education \\ Department \\ Faculty of Social Sciences, Manado \\ Universitas Negeri Manado \\ Tondano, Indonesia \\ maxikeintjem@unima.ac.id
}

\begin{abstract}
The research includes survey research used for descriptive purposes and methods used in qualitative descriptive aimed to focus attention on actual problems. The data collected is arranged, explained and then analyzed. The data collection is direct observation and interviews on the object, namely the teachers who teach civics Public Middle School in Siau, Sitaro Regency. Data obtained from various sources using various data collection techniques (triangulation). The results showed Civics teachers who teach at Siau Junior High School in Sitaro regency islands were certified as professional teachers in Civics teaching. Some teachers have not been certified to work as honorarium workers funded by the local government. Teachers who are not professionally juridically but, conducting their duties to successfully. The reality occurs if the performance of Civics teachers is not optimal due to transportation and communication problems in the location of the school is very far from the center of the town, to access innovative learning materials and learning media is very limited.
\end{abstract} Civics

Keywords: Analysis, competence, professional, teacher,

\section{INTRODUCTION}

Law No. 20 of 2003, emphasizes education is a conscious and planned effort to create an atmosphere of the learning process for students actively develop their potential to have spiritual strength, self-control, personality, intelligence, noble character, and the necessary skills himself and the community. Education is seen as an appropriate way to shape quality human resources (HR) and to support the creation of national development goals. Education is a prospect that should produce quality graduates according to the needs of stakeholders. As reference [1] stated the concept of external efficiency in the education system is called the relevance of education to the needs of graduates, society, and development. Therefore, the implementation of human education is directed to gain knowledge, skills, values, and attitudes, to think more systematically, more rationally and more critically about all the problems faced.

To achieve the goals intended above, the school is an institution that has a strategic role, especially to educate and prepare quality human resources in holding the previous generation relay. The school is expected to be able to develop students' talents and interests through the development of student activities. To achieve the educational goals needed a process of the existing input can produce maximum output according to be expected.

In this case, one factor that plays an important role is the teacher, where the presence of the teacher is a very significant factor. The teacher is a determining factor in the implementation of the teaching and learning process in schools or on the formal education path. Therefore, in every effort to improve the quality of education in our beloved country we cannot be separated from various things related to the efforts of the teacher himself. This is as stated by reference [2] which confirms "teacher" means as a professional educator with the main task of educating, teaching, guiding, directing, training, evaluating, and evaluating students on the formal education path. The main task will be effective if the teacher has a certain degree of professionalism is reflected in competencies or skills which meet certain quality standards or ethical norms.

Furthermore, when examining the competence of teachers, they should receive serious attention from various groups including the government. The issuance of Law No. 14 of 2005 concerning teachers and lecturers, where teachers should have four competencies namely personality competence, pedagogical competence, professional competence, and social competence. All teachers of any subject should have the competency in question, It can be said the teacher has been standardized according to applicable regulations, and one of them is a Civics teacher. Civics teacher is very much needed to create Indonesian people as a whole, and its implementation is through the implementation of teaching and learning activities in class according to the development and progress of Civics and the need to use various models of approaches, in which there are teaching methods in Civics learning it is expected will achieve the expected goals for students who have comprehensive competencies.

In Government Regulation (PP) No. 19 of 2005 concerning the National Education Standards Agency (BSNP) it is emphasized that Educators (Teachers) should have competence as agents of learning at the level of primary and secondary education and early childhood education. The directive states that the teacher as an agent of learning shows 
the hope that the teacher is the first party most responsible for providing knowledge to students.

The teacher has a duty and responsibility as a professional educator with the main task of educating, teaching, guiding, directing, training, assessing and evaluating students in early childhood education through formal education, basic education, and middle education. However, based on various phenomena that occurred regarding the existence of teachers who teach PKn (Civics) at SMP (Middle School) of Siau Islands, Sitaro Regency, there are still teachers who teach Civics subjects not having professional competence in their fields. A problem will occur teachers who teach formally not be able to teach according to the characteristics of Civics subjects. Civics courses have their characteristics from other subjects, moreover, the orientation of Civics teaching is the affective domain of students. Also, the phenomenon occurs is not by the applicable laws and regulations concerning the competencies that should be possessed by a teacher, in this case, the subject teacher Civics.

\section{RESEARCH METHODS}

This research is survey research used for descriptive purposes. The method used in this study is a qualitative descriptive method where this method aims to focus on actual problems, the data collected is arranged, explained and then analyzed.

Data collection used in this study as follows: (1) Observation, the researcher makes direct observations on the object of research, namely all teachers teaching PKn at SMP of Siau Sitaro Regency; and (2) interview is a method of collecting data that is used to obtain information directly from the source. Interviews are used as data collection techniques if the researcher wants to conduct a preliminary study to find problems that need to be investigated, but also the researcher wants to know things from respondents in more depth [3]. The researcher communicates with parties related to this research to be used as supporting data in completing the data obtained, namely the Sitaro Education Office and the teachers who teach PKn at SMP of Siau, Sitaro Regency.

In qualitative research as stated by [3], Data can be obtained from various sources using various data collection techniques (triangulation) and conducted continuously until the data is saturated. In qualitative data analysis, Bogdan states this data analysis is the process of systematically searching and compiling data obtained from interviews, field notes, and other materials, they can be easily understood, and their findings can be shared with others.

\section{RESULTS AND DISCUSSION}

\section{A. Research result}

The results of this study use a descriptive analysis method in the form of narratives of professional competencies of teachers in teaching and learning. The data obtained through direct observation and interviews were first collected, compiled, explained and then analyzed and discussed by the focus of the problem in this study. The focus of the discussion is in terms of the professional competence of Civics teachers who teach in West Siau of
Junior High School, Ondong District, Sitaro Regency. The analysis and discussion will be put forward below.

The professional competence of Civics teachers intended in this study is the ability possessed by teachers who teach according to their scientific fields. Furthermore, the competencies possessed are shown in all activities conducted in each day as proof of their performance in school. Where the teacher performs his main task as an educator and instructor by conducting teaching and learning activities in schools or classes can form student competencies according to the orientation of Civics learning, namely as value education. The teacher should be able to internalize some morality values. They can shape the democratic character of students. This is in line with the opinion of reference [4] who explained character value education should be conducted to educate citizens. Besides being stated character education is needed to foster life too follows the rules of values and norms. The teacher should be able to conduct the task as a professional as the intended expectations are achieved. In case to obtain an overview of the analysis and evaluation according to the focus of this study, the researchers describe it as follows:

\section{Teacher Competency}

According to Law No. 14 of 2005 concerning Teachers and Lecturers Article 1 Paragraph 10, which explains that "Competence is a set of knowledge, skills, and behaviors that should be possessed, internalized, and mastered by the teacher or lecturer in conducting professional tasks. Therefore, it is clear that regulations require a teacher should have competence, is needed in conducting their main duties and functions as educators and instructors in schools. Teachers who have competencies according to existing rules namely pedagogic competencies, personality competencies, professional competencies, and social competencies are appropriate to conduct their duties both at school and in the community.

Based on observations and interviews at South West Siau Junior High School, where 8 teachers are teaching in Civics in 6 schools who have the competencies intended in the teacher and lecturer law. Despite the fact, Civics teachers who have competence vary greatly from one another according to the ability of the teacher itself and the conditions and environment of the school where they teach. For example, the data obtained by researchers in which Civics teachers who teach at SMP Negeri 4 West Siau and Civics teachers who teach at SMP Negeri 1 Siau Barat Selatan have differences in the actualization of their teaching and teaching abilities. This is according to the field data that researchers obtained, whereas Civics teacher at SMP Negeri 4 West Siau has teaching experience has 26 years of teaching, whereas Civics teachers who teach at SMP Negeri 1 Siau Barat Barat have new teaching experience of 9 years as an honorary teacher. Two teachers differ in terms of competency as educators and teachers in schools, even in the actualization of social competence.

\section{Professional Competence}

The results of research on the professional competence of Civics teachers in West Siau Junior High School in Sitaro Regency, researchers obtained by observing and interviewing informants, namely 8 teachers teaching Civics spread in 6 schools. The data collected by researchers are then analyzed according to indicators determined based on the opinion of reference [5], which are as follows: (1) skills 
to develop and process knowledge (2) critical thinking skills, creative, and innovative and ( 3 ) conducting teacher training with high ability. For analysis results according to these indicators, the following can be stated.

\section{Skill Indicators for Developing and Processing Knowledge}

The data obtained through observation and interviews with several informants namely Civics teacher in six schools, and analyzed according to the informants' questions and answers concerning how the father/mother in preparing the material or subject for teaching in class? it turns out there are informants who answered and analyzed according to the results of the analysis above, it can be said that the professional competence of teachers who teach Civics in several State Junior High Schools exist in several schools shows the competence possessed in terms of the ability to manage and develop knowledge in conducting its main tasks as an educator and teacher.

\section{Indicators of Critical, Creative, and Innovative Thinking Skills}

To get data and information about the professional competence of Civics teachers in West Siau Junior High School, researchers conducted interviews with informants namely Civics teachers who in several schools about whether the father/mother conduct the task of educating and teaching by preparing and teaching material textually or contextually which can form the competencies of students to think critically, creatively and innovatively? It was found based on the answers of several informants, it can be said the professional competence of Civics teachers in the West Siau Junior High School showed an effort to develop the knowledge of students who could think creatively, creatively and innovatively.

\section{Indicators Conduct Teacher Training with High Ability}

The task of educating and teaching the teachers of Civics in Schools of West Siau shows there is a professional ability to conduct teacher training with high ability, and this can be demonstrated based on interviews conducted with informants whether the father/mothers who teach apply innovative models, manage classes and use media are relevant to the subject matter? It was found based on the informants' answers which showed that when teaching civics teachers try to apply innovative learning models such as cooperative, inquiry, etc. that are adapted to the subject matter.

It also prepares learning media, and when teaching if there are students who are not serious about teaching, class management is done by moving the student from his seat to another seat. Therefore, the teacher who teaches is satisfied in general students who take Civics courses can understand and seriously complete the assignments given either done in class or to be done as homework.

\section{B. Discussion of Research Results}

The overall results of the analysis examine the professional competence of Civics teachers in several West Siau Middle Schools conduct their main duties and functions as educators and instructors. Furthermore, based on the results of the analysis interview, this section will be discussed in detail related to the topic and research problem for discussion according to the focus established as an indicator of professional competence consisting of: (1) indicators of skills to develop and process knowledge (2) skills think critically, creatively, and innovatively and (3) conduct teacher training with high ability. In detail, each of the above indicators will be discussed as follows:

\section{Teacher Competency}

In-Law No. 14 of 2005 concerning Teachers and Lecturers Article 1 Paragraph 10, "Competence is a set of knowledge, skills and behaviors should be possessed, internalized, and mastered by the teacher or lecturer in conducting professional duties." Then in more detail in the law Article 1 Paragraph 1, explains the teacher is a professional educator with the main task of educating, teaching, guiding, directing, training, evaluating, and evaluating students in early childhood education formal education pathways, basic education, and secondary education. Furthermore, in government regulation (PP) No. 74 of 2008 concerning Teachers, the term Teachers include: (1) the teacher himself, both the class teacher, the field of study teacher, as well as the guidance and counseling teacher or career guidance teacher; (2) teachers with additional duties as school principals; and (3) teachers in supervisory positions.

According to the results of data analysis about the competence of Civics teachers in several West Siau Public Middle Schools, it can be explained the competencies possessed by teachers as learning agents include pedagogical, social, personal and professional competencies. Civics teachers in the school where this study is competent, although there are differences in each teacher because the teaching experience is different in terms of the length of time being a teacher, PNS, and honorary teachers. However, it can be said in general teachers in West Siau Junior High Schools have competence, which is pedagogic, the ability to manage the learning of students who meet pedagogical rules. Personality competencies are competencies that should be possessed by teachers regarding personal wisdom, noble character, and be an example for students. Social competence is the ability of teachers to communicate and interact socially with all parties including students, and professional competence is the ability of teachers to show their skills as professional teachers [6].

\section{Professional Competence}

The professional competency intended in this study is according to Law No. 14 of 2005 concerning teachers and lecturers, especially article 1 Paragraph 1 , which explains the teacher is a professional educator with the main task of educating, teaching, guiding, directing, training, assessing, and evaluating students in education. The teacher performs the duties and main points and functions as educators and instructors, and this is the position of the teacher.

The position of teacher is known as a professional occupation and formally, to become a professional teacher is required to meet the minimum academic qualifications of educator-certified. Teachers who meet these professional criteria will be able to conduct their main functions effectively and realize the process of education and learning to achieve national education goals, namely the development of the potential of students to become people of faith and piety, noble, healthy, knowledgeable, competent, creative, independent, and become citizens who are democratic and responsible [7].

Also stated by reference [5], teachers as professional educators and instructors are demanded to be able to improve 
their abilities, insights, and creativity to influence each other. The community and parents have entrusted some of their work to the teacher. The task of the teacher is quite noble and heavy, due to the abundance of tasks of the community and parents, among others, the ability of teachers to transfer knowledge and culture in a broad sense, life skills, values, and beliefs. The teacher is expected to create a condition of the learning process based on learning competency means the results are clear. Teachers with their abilities are expected to develop and build three pillars of skills, namely as follows: 1) Learning skills, namely skills to develop and process knowledge and experience as well as the ability to undergo long-life education. (2) Thinking skills, namely critical, creative, and innovative thinking skills to produce an optimal decision and problem-solving. (3) Living skills, which are life skills include emotional and social maturity and lead to high levels of struggle, responsibility, and social sensitivity.

According to the results of the data analysis, it can be said that there are 4 Civics teachers in West Siau Public Middle Schools, 4 teachers who have been certified and as PNS teachers. While 4 teachers teach that have not been certified and in the category of honorary staff of the Sitaro local government. In conducting their duties, even though they are still honorarium and not certified, they still conduct their duties professionally. For teachers who have been certified, they conduct their duties professionally, moreover, they are required according to the rules to realize the teacher's performance required by law.

Furthermore, it can be stated based on the observations made by the researcher, the teacher submits and presents the subject material by selecting and filtering the lesson material and understanding the basis and objectives of education. By processing the lesson material the teacher becomes an evaluator or assessor who provides encouragement and motivation and becomes an example for his students. The teacher is seen giving questions randomly and placing themselves in the middle of the students. If anyone does not understand the material being taught, the field of study teacher guides them. But there are still some students who do not care about the situation, due to the observations there are students who are depressed, playing, even just being quiet when asked.

Besides, Civics teachers in several schools in the locations of this study can be stated have emotional and intellectual abilities due to emotional intelligence will guide teachers to be able to understand students' feelings according to their ability and age levels, as well as the intellectual abilities of teachers to place yourself as someone who has a special attraction for students. In the current global competition, Civics teachers in these schools are trying to meet the demands of existing professional standards and placed as a top priority if teachers want to improve their professionalism, they sustainably develop professionalism by taking reflective actions. They develop learning material creatively, so we can provide sustainable change. Civics teachers who teach in several schools classified as professionals can take responsibility for the implementation of the task to the public. It means they are providing excellent service to their service users, namely students, parents, and schools. There are even efforts to provide innovation and develop creativity in the use of the latest communication and information technology.

\section{CONCLUSION}

Based on the description above, it can be concluded that several main points related to the focus in this study are as follows: (1) Civics Teachers in several public schools in West Siau Junior High School have different competencies according to the teacher's personality, length of teaching time, teaching experience including the ability to teach, as well as the condition of the school and its environment; (2) Civics teachers who have not been certified are certainly not said to be professional teachers, but in conducting their main tasks and functions as educators and instructors they can become certified teachers; (3) There are also a small number of teachers who have not the maximal ability in conducting their roles and functions in applying each competency to students. Where there are still students who in the teaching and learning process do not understand and comprehend the material conveyed by the teacher. students also participate; and (4) In today's global competition, Civics teachers in West Siau State Junior High School are trying to meet the demands of existing professional standards and are placed as the main priority if teachers want to improve their professionalism, they sustainably develop professionalism by taking reflective actions.

\section{ACKNOWLEDGMENT}

The author would like to the Dean of Faculty of Social Science, Manado State University in supporting the publication of this article.

\section{REFERENCES}

[1] A. Suryadi, Pendidikan, Investasi SDM, dan Pembangunan. Bandung: Widya Aksara Press, 2012.

[2] Mulyasa, Menjadi Guru Profesional menciptakan pembelajaran kreatif dan menyenangkan. Bandung: Remaja Rosdakarya, 2005.

[3] Sugiyono, Metode penelitian uantitatif, kualitatif dan R\&D. Bandung: Alfabeta, 2011.

[4] B. Dasim, Perancangan Pembelajaran Berbasis Karakter. Seri Pembinaan Profesionalisme Guru. Bandung: Widya Aksara Press, 2018.

[5] T. C. K., Wikipedia Untuk Guru. Bandung: PT Globalindo Universal Multikreasi, 2008.

[6] A. Hadis and B. Nurhayati, Manajemen Mutu Pendidikan. Bandung: Alfabeta, 2010.

[7] S. Danim, Pedagogi, Andragogi, dan Heutagogi. Bandung: Alfabeta, 2010. 